\title{
Organizational Citizenship Behavior among Local Government Employees in East Coast Malaysia: A Pilot Study
}

\author{
Rashidah Mohamad Ibrahim ${ }^{1}$, Mazuri Abd Ghani ${ }^{1}$ \& Ahmad Munir Mohd Salleh Embat ${ }^{2}$ \\ ${ }^{1}$ Faculty of Business Management \& Accountancy, Universiti Sultan Zainal Abidin, Terengganu, Malaysia \\ ${ }^{2}$ Faculty of Management \& Economics, Universiti Malaysia Terengganu, Terengganu, Malaysia \\ Correspondence: Rashidah Mohamad Ibrahim, Faculty of Business Management \& Accountancy, Universiti \\ Sultan Zainal Abidin, 21300 Kuala Terengganu, Terengganu, Malaysia. Tel: 60-9-668-8258. E-mail: \\ rashidahmi@unisza.edu.my
}

Received: March 19, 2012

Accepted: May 2, 2013

Online Published: May 17, 2013

doi:10.5539/ibr.v6n6p83

URL: http://dx.doi.org/10.5539/ibr.v6n6p83

\begin{abstract}
A pilot test was carried out to determine the suitability, validity and reliability of a survey instrument in preparation for a large scale study to be undertaken involving one of the important public sector namely local governments. Content and face validity was initially carried out through a panel of expert where some modification and alteration to the original set was made taking into account that local governments' employees are majority Malays with basic tertiary education level and are support staff category (low to middle level management staff). Data obtained from pilot testing was analyzed where the values of Cronbach's alpha for all variables exceeded the 0.6 benchmark, an indication that the reliability of the scale instrument was reliable. Normality tests indicated that the data was normally distributed and the assumptions of linearity and homocedasticity in the multivariate analyses have been fulfilled. Demographic profile and descriptive statistics of the respondents were tabled out and analyzed. It is envisaged that the measurement tool will contribute in elevating organizational citizenship behavior (OCB) level among local governments' employees as OCB has been identified as a vehicle to promote overall organizational effectiveness at a relatively low cost.
\end{abstract}

Keywords: organizational citizenship behavior, local government, leader-member exchange, organizational communication, job satisfaction, pilot test, Malaysia

\section{Introduction}

In a highly competitive world, the biggest challenge for any organization whether it is private or public sector, is to manage and motivate its valuable asset, its employees, in achieving the organization's objectives and in sustaining its competitive advantage. There are increasing pressures for organizations to be lean, dynamic, proactive, quick responding, team-based, efficient, empowering and innovative (Lapierre \& Hackett, 2007). In public sector context, the ability to respond effectively to the changing needs of the environment is a key factor in ensuring a nation's sustainable development, growth and global competitiveness (Kandan \& Ibrahim, 2010). In order to meet these factors, it is crucial that the public sector employees are able to deliver quality products and services to the satisfactions of the specific end-users and to the public in general. Thus, there is a need for organizational citizenship behavior (OCB) to be exhibited by all employees as according to Organ (1988), OCB is considered as one of the most important factors influencing organizational effectiveness. Furthermore, OCB is positively related to high job performance, cost reduction; improve operational efficiency, employees' retention and customer satisfaction (Podsakoff, Whiting, Podsakoff \& Blume, 2009).

OCB includes employees' discretionary actions not explicitly recognized by a formal reward system that in aggregate promote effective functioning of the organization (Organ, 1988). As noted by Vigoda and Golembiewski (2001), OCB is particularly critical in enhancing governmental effectiveness, since it can supplement formal bureaucratic operations that may be somewhat restricted by limited administrative and financial resources or protocols. Hence, governmental operations can be managed with greater efficiency and services delivered with higher quality whenever employees interact with stakeholders and the public in ways that exhibit the positive actions associated with OCB. By demonstrating high OCB, the image of the public sector as the engine of economic and social growth for the nation can be strengthened and fortified. 
Local Government, being the government's lowest tier after Federal and State governments, has become one of the most important agencies to drive the economic growth and social development of a particular district and its residents as they are managers of urban environments. However, their performance have been subjected to various criticisms and being barraged with questions and complaints directly via electronic and written media and tougher higher ups at the state and federal levels, suggesting the inefficiency and ineffectiveness of the local government management (Zaherawati, Zuriawati \& Mohd Zool Hilme, 2010). Local governments have often been criticized for their poor services, bureaucratic, inefficient, wasteful, unresponsive and not citizen-friendly and the allegations of bribery and misuse of power were frequently raised by the public (Hazman \& Kalianan, 2008; Danilah \& Siti Nabiah, 2011). Hard evidence from 2009 to 2011 annual reports of Public Complains Bureau revealed that local government was among the highest number of complaints made by the public towards the public sector (Public Complaints Bureau).

In response to the high level of complaints filed against the local governments is the driving force behind undertaking this study. To this extent, three main factors have been identified that can promote the employees' OCB and they are leader-member exchange (LMX) which refers to the differential relationship between a leader and a subordinate, organizational communication which refers to the flow of communication and interactions among members in an organization and job satisfaction which refers to attitudes associated with the degree to which people like or dislike their job. Literature reviews of these variables of interest are elaborated in the ensuing section. Hence, the objectives of this study are to identify the relationship between LMX, organizational communication and job satisfaction towards enhancing OCB level among the local governments' employees.

The remainder of this paper is structured as follows where a literature review of the variables of interest are discussed follows by methodology incorporating description of the instruments being used and the procedures undertaken in pilot testing. Then, analysis and results arising from the pilot test shall be elaborated and discussion concludes this paper.

\section{Literature Review}

A review of literature is undertaken to discuss and elaborate the main variables of interest namely OCB, organizational communication, LMX and job satisfaction. Besides that, an overview of local government setting is put forward to better understand the nature of this important government sector as the engine of growth of a particular district.

\subsection{Local Government}

The Malaysian government is being structured into a three-tier government: the federal government being the upper or center government follows by state government and lastly the local government which is the lowest level government. According to Ministry of Housing and Local Government, local government is categorized into three levels of hierarchy namely city council for city centers, municipal council for larger towns and district council centers for small urban town. At present, there are 149 local governments which consist of 12 city councils, 39 municipal councils and 98 district councils of which 99 of them are located in Peninsular Malaysia, 24 located in Sabah and the balance 26 in Sarawak (Ministry of Housing and Local Government, 2012). The local government in Peninsular Malaysia follows the Local Government Act 1976 whereas Sabah and Sarawak (East Malaysia) follow their own respective Local Government Ordinances.

The local government, in general, is under the jurisdiction of the state government and the power of decision-making is transferred to the local government to administer in its respective area. The local government has the power to collect taxes and to create laws and rules as well as granting licenses and permits for any trade in their areas. Besides that, the local government has the responsibility to safeguard public health and sanitation, environmental protection and building controls, social and economic development and general maintenance functions of urban infrastructure within its jurisdiction (Hazaman \& Kalianan, 2008).

\subsection{Organizational Citizenship Behaviour}

OCB referred to some discretionary behavior of individuals' that are unrecognized by direct or explicit formal reward system and promotes the effective functioning of the organization in aggregate (Organ, 1988). OCB can enhance organizational performance because they lubricate the social machinery of the organization, reduce friction and increase efficiency (Bateman \& Organ, 1983). Most OCB actions, taken singly, would not make a dent in the overall performance of the organization. The effect will be seen with the aggregate summation of OCB performed across time and across persons in the group, department and organizational levels (Organ, 1988). It is the behavior that are clearly observable by peers, supervisors or the public at large (Noormala \& Syed Shah Alam, 2009). Murphy, Athanasou and King (2002) reiterated that OCB is vital to the survival of an organization, in the 
sense that OCB can maximize efficiency and promote effective functioning of an organization. In other words, OCB is an employee's beneficial behaviors that leaders want but cannot require (Motowildo, 2000).

OCB has been recognized as a key factor for individual and organizational performance (LePine et al., 2002; Chughtai \& Zafar, 2006; Chahal \& Mehta, 2011). In general, organization with a higher degree of OCB leads to reduced absenteeism and turnover, increased employees' satisfaction and retention which subsequently lead to improved organizational performance and success and customers' satisfaction and loyalty.

\subsection{Leader-Member Exchange and Organizational Citizenship Behavior}

LMX theory describes the relationship between a leader and a subordinate and how they influence each other in an organization and their interdependencies resulting in the formation of in-group and out-group (Yukl, 2006). As noted by Hui, Law \& Chen (1999), subordinates with whom the leaders share valued resources such as time, information and personal support (in-group) tend to consistently perform OCB with passion as compared to those whose leaders adhere to contractually establish job roles (out-group). A study by Hackett, Farh, Song \& Lapierre (2003) reported a meta-analysis mean correlation of 0.32 between LMX and overall OCB, leading them to conclude that OCB plays a key role in the reciprocal social exchange process of LMX. On the contrary, leaders' differential treatment towards the subordinates in the workplace can cause problems. A study by Zellars, Tepper $\&$ Duffy (2002) on the effect of differential treatment by leader towards the subordinates revealed that subordinates may withhold OCB in case of the supervisors are exploitative to the extent that the subordinates feel abused. Another damaging effect on the differential treatment by supervisors is that it may elicit workplace jealousy among subordinates or they may trigger different frequencies and patterns of communications among subordinates (Zellars et al., 2002).

The key to subordinates' involvement in OCB lies in the hands of the leaders. Obviously, the effectiveness and the willingness of subordinates in performing OCB are very much depended on the leadership effectiveness and the relationship being established. Thus, the relationship between leader and subordinate has been suggested to be one of the most important relationships for employees (Mazoni \& Barsoux, 2002).

\subsection{Organizational Communication and Organizational Citizenship Behavior}

Communication is one of the most dominant and important activities in an organization (Harris \& Nelson, 2008). As defined by Berger (2008), organizational or internal communications refers to communications and interactions among members within an organization. Communication is vital for an organization since it is the vehicle of human interaction and the basis for its members to make sense of their organization, what it is and what it means. Organizational communication helps to motivate, build trust, create shared identity and spur engagement; it provides a way for individuals to express emotions, share hopes and ambitions and celebrate and remember accomplishments (Berger, 2008).

Communication takes places on three levels namely interpersonal, group and organizational communication (Berger, 2008). The first level is interpersonal or face-to-face communication between individuals which is a primary form of communication. The second level is through group-level communication which occurs in teams, units and interest group with the focus on information sharing, issue discussion, task coordination, problem solving and consensus building. The last level is the organizational-level communication which focuses on such matters as vision and mission, policies, new initiatives, organizational knowledge and performance (Berger, 2008). Communication can be formal which follows the formal structure of an organization or informal which is based on social relationships (Kandlousi, Ali \& Abdollahi, 2010; Guffy, Rhoddes \& Rogin, 2005) and can flow in downward, upward and cross-wise directions (Ayatse, 2005). Study by Ayatse and Ikyanyon (2012) provided evidence that organization communication is an important predictor of IT employees in Nigerian universities which implies that employees' citizenship behavior will be increased when they are satisfied with the communication channels and processes in the organization. Another study by Kandlousi, Ali and Abdollahi (2010) supported the findings that a relationship existed between OCB and organizational communication.

\subsection{Job Satisfaction and Organizational Citizenship Behavior}

Job satisfaction as defined by Weiss, Dawis, England and Lofquist (1967) as the attitudes and viewpoints of workers regarding their jobs and the relevant environments including intrinsic and extrinsic satisfaction. Intrinsic job satisfaction originates from within individuals and has psychological value such as independence and achievement of job. Extrinsic satisfaction, on the other hand, is related to job itself such as salary and co-workers.

Numerous studies have shown that OCB and job satisfaction are positively related (Organ \& Ryan, 1995; Le Pine, Erez \& Johnson, 2002; Foote \& Tang, 2008). Job satisfaction has been found to have positive relationship with job performance and OCB which in turn can help in reducing employees' absenteeism, turnover and psychological 
stress (Chahal \& Mehta, 2010). Foote \& Tang (2008) found that job satisfaction and OCB were significantly correlated and the association between them becomes stronger when high team commitment moderated the relationship. A meta-analysis study by Harrison, Newman \& Roth (2006) found support those employees holding negative attitudes (such as job satisfaction) were likely to reduce time and effort put into their jobs as well as their OCBs. Another study by Simons and Peterson (2000) revealed that relationship conflict causes tension and anxiety among employees which lowers the citizenship behavior and can harm team effectiveness and member's satisfaction about job.

\section{Methodology}

In order to obtain a better understanding on the local government settings as well as in-depth knowledge of the variables of interest, extensive library searches, journal articles, newspaper articles including online databases were reviewed. Besides that, related websites such as portals of Ministry of Housing and Local Government and various local governments were accessed and referred to. In addition to secondary searches, visits to a few local governments were made to obtain first hand information on the nature, work procedure and policies where discussions with the staff were conducted. Their perceptions towards the concept of OCB being practiced in their organizations and the challenges faced by them in meeting the organizations' goals and the public expectations on quality service delivery were discussed.

\subsection{Research Instruments}

The survey instruments used for this study are adapted from established instruments with proven reliability and validity. Since these instruments are originated from the West, they are translated to Malay language with some alteration and modification to suit with the respondents who are predominantly Malay, having a basic tertiary education level and worked in the support staff category. A close-ended survey instrument is the mode for collecting the data for this research. As the items in the survey instrument are targeted to measure the respondents' perceptions and attitudes, Likert-type scale is considered more appropriate and reliable (Alreck \& Settle, 1995). Furthermore, a close-ended survey instrument would assist the respondents in answering these items which are mutually exclusive and collectively exhaustive (Sekaran \& Bougie, 2010) and as suggested by Malhorta (2007) it is relatively easy to administer, very economical and efficient in reaching the target population. The survey instrument is divided into five parts: demographic information and four scales to measure OCB, LMX, organizational communication and job satisfaction using a five-point Likert scale ranging from strongly disagree to strongly agree. The measurements of each construct are discussed as follows:

\subsubsection{Organizational Citizenship Behavior}

This variable is assessed with 22-item scale developed by Podsakoff et al. (1990) based on the five dimensions proposed by Organ (1988) and they are altruism, conscientiousness, sportsmanship, courtesy and civic virtue. Podsakoff et al. (1990) reported a strong reliability coefficient ranging from 0.70 to 0.85 . Le Pine, et al. (2002) in their review and meta-analysis stated that the scales developed by Podsakoff et al. (1990) has been used in numerous studies, thus perhaps making it the most utilized scale of OCB. A meta-analysis of OCB literature by Hoffman, Blair, Meriac and Woehr (2007) suggested that the operationalizations of OCB are best viewed as indicators of a general OCB factor. This recommendation was also supported by LePine et al. (2002) who reported that predictive relationships with the broader OCB criterion are as good as, or superior to, those with narrower dimensional criteria. Thus, for this study, the latent construct is used in measuring the OCB level among the local governments' employees.

\subsubsection{Leader-Member Exchange}

The scale developed by Liden and Maslyn (1998) is chosen for this study as it has broader domain coverage and better reflects the subordinate's evaluation of the relational characteristics and qualities of the supervisor subordinate relationship than do other uni-dimensional measures of LMX (Wang, Law, Hackett, Wang \& Chen, 2005). Furthermore, Liden, Wayne and Sparrowe (1997) contended that in order to capture the complexity of LMX, the multidimensional construct would be better to gauge the exchange relationship between individuals. The four dimensions as categorized by Liden and Maslyn (1998) are affect (mutual affection members of the dyad have for each other based on interpersonal attraction), contribution (perception of the current level of work-oriented activity each member of the dyad puts forth), loyalty (expression of social support among each member of the dyad) and professional respect (perception of each member of the dyad has built a reputation of work-related activity). A confirmatory factor analysis with AMOS 5.0 of the four-dimensional structure of LMX showed that the four-factor model fitted the data reasonably well with coefficients alpha ranged from 0.80 to 0.92 (Ansari, Kee \& Aafaqi, 2007). 


\subsubsection{Organizational Communication}

Communication Satisfaction Questionnaires (CSQ) developed by Downs and Hazen (1977) with seven dimensions is chosen for this study to assess employee satisfaction with internal communication. Downs \& Hazen (1977) reported a 0.94 test-retest reliability coefficient for CSQ. Gray \& Laidlaw (2004) commented that the said questionnaires is one of the most comprehensive instruments available because it assesses the direction of information flow, the formal and informal channels of communication, relationships with various members in the organization, and the forms of communication. For this study, seven dimensions developed by Downs and Hazen (1977) shall be grouped into three categories: interpersonal contexts which comprises of personal feedback and supervisory communication, group contexts which comprises of co-worker communication and organizational integration and organizational context which comprises of corporate communication, communication media and media quality (Mueller \& Lee, 2002).

\subsubsection{Job Satisfaction}

The short version of the Minnesota Satisfaction Questionnaire (MSQ) developed by Weiss, et al. (1967) is used to measure the individual's satisfaction with different aspects of the work environment. Consisting of 20-items, the MSQ short version has reported a strong reliability with coefficient alpha values within the range from 0.85 to 0.91 (Field, 2003). Based on the recommendation by Hancer and George (2003), the latent construct is used in measuring the overall level of satisfaction score.

\subsection{Content and Face Validity}

The translated survey instruments underwent content and face validity to ensure that the survey instrument measures what is supposed to measure (Hair, Black, Babin \& Anderson, 2010). The process involved consulting a small sample of typical respondents and/or panel of expert to pass judgement on the suitability of the items selected to measure the constructs (Sekaran \& Bougie, 2010). In undertaking the process, pre-testing was conducted where the survey instruments were distributed to six lecturers (of which two were $\mathrm{PhD}$ scholars and were familiar with the environmental context of the proposed study) and four government employees. The objectives of pre-testing the survey instrument were to get their feedback regarding the content and layout of the questionnaire, to investigate the adequacy of the items being measured, to check on the clarity and also to estimate the time needed to answer the survey instrument. Based on the feedback and recommendations obtained, a number of questions were re-phrased to enhance the understandability of the survey instrument taking into account that the majority of the respondents have basic tertiary education level. Furthermore, those items that carry double meanings are separated and split into single item so as to avoid confusion. The improved/revised version of the survey instrument was ready to be pilot tested under an administered environment.

\subsection{Pilot Test}

The main purpose of the pilot test is to test the survey instrument on a small sample of respondents where it can be considered to be like "a dress rehearsal" where a small scale trial of the study is conducted prior to the full scale study (Gaye, Mills \& Airasian, 2006). Conducting a pilot test is important in order to make an assessment on the suitability, reliability and appropriateness of the data collection instruments and to further improve the survey procedures (Sidek, 2000). Besides that, pilot testing would enable the researcher to anticipate and adjust to potential drawbacks during the full scale research to be undertaken.

As part of an ongoing project and in line with the recommendation by Malhorta (2007), the sample size of the pilot study is small around 15 to 30 respondents. The pilot test was conducted under an administered situation where 32 respondents from one unit in Majlis Bandaraya Kuala Terengganu (city council) were invited to participate. These respondents were considered the target group in term of job description and structure and these criteria should be similar to the actual research to be conducted. A brief explanation was given to the respondents informing them on the objectives of the study so that they would have a clear understanding of what were expected from them. Assurance was also given to them that their responses would be make confidential and were used for the exclusive purpose of this study only. The pilot test was being administered personally and as such any ambiguities were clarified on the spot. Besides that, any suggestions made by the respondents to further improve the survey instruments were taken in consideration. An average time between 20 to 25 minutes was taken by the respondents to complete the survey.

\section{Data Analysis and Results}

This data collected was keyed-in and analyzed using SPSS version 19 for windows. A number of analyses were carried out in this pilot study which includes descriptive statistics, frequency distribution and reliability test. 
Besides that, normality test, linearity and homocedasticity test were conducted in meeting the assumption in multivariate analysis (Hair et. al, 2010).

\subsection{Profiles of Respondent}

Out of 32 respondents, male dominated the sample with $65.6 \%$ compared to the female counterpart of $34.4 \%$, with all of them were Malays. $93.8 \%$ of the respondents were from the support staff category (low to middle level management) which is typical of a local government with the support staff category dominating the workforce. Majority of the respondents $(84.4 \%)$ have completed their tertiary level of education and in commensurate with their attained level of education, most of them $(90.6 \%)$ earned a monthly income bracket of RM1000 to RM3000. As the local government is a state owned agency and a close service organization, 78.1\% of the respondents have worked for more than 10 years out of which $40.6 \%$ has been in the same organization for more than 21 years. In terms of their immediate supervisors, most of them have a male supervisor $(75 \%)$ and the majority of them (53.1\%) have worked with the current supervisor for less than five years which gave an indication that job rotation being practiced in the said organization.

Table 1. Demographic profile of respondents

\begin{tabular}{|c|c|c|}
\hline Items & Frequency $(\mathrm{N}=32)$ & Percentage $(\%)$ \\
\hline \multicolumn{3}{|l|}{ Gender } \\
\hline Male & 21 & 65.6 \\
\hline Female & 11 & 34.4 \\
\hline \multicolumn{3}{|l|}{ Age } \\
\hline Less than 25 years & 1 & 3.1 \\
\hline $26-35$ years & 4 & 12.5 \\
\hline $36-45$ years & 11 & 34.4 \\
\hline 46 years and above & 16 & 50.0 \\
\hline Race & 32 & 100 \\
\hline \multicolumn{3}{|l|}{ Monthly Income } \\
\hline RM1000 - RM2000 & 16 & 50.0 \\
\hline RM2001 - RM3000 & 13 & 40.6 \\
\hline RM3001 - RM4000 & 2 & 6.3 \\
\hline RM4000 and above & 1 & 3.1 \\
\hline \multicolumn{3}{|l|}{ Service category } \\
\hline Support I & 20 & 62.5 \\
\hline Support II & 10 & 31.3 \\
\hline Professional and Administrative & 2 & 6.2 \\
\hline \multicolumn{3}{|l|}{ Education qualification } \\
\hline Higher School Certificate and below & 27 & 84.4 \\
\hline Certificate & 2 & 6.3 \\
\hline Diploma & 1 & 3.1 \\
\hline Bachelor's Degree and above & 2 & 6.2 \\
\hline \multicolumn{3}{|l|}{ Years of service } \\
\hline Less than 5 years & 3 & 9.4 \\
\hline $5-10$ years & 4 & 12.5 \\
\hline $11-15$ years & 4 & 12.5 \\
\hline $16-20$ years & 8 & 25.0 \\
\hline 21 years and above & 13 & 40.6 \\
\hline \multicolumn{3}{|l|}{ Gender of current supervisor } \\
\hline Male & 24 & 75.0 \\
\hline Female & 8 & 25.0 \\
\hline \multicolumn{3}{|l|}{ Years of service with current supervisor } \\
\hline Less than 5 years & 17 & 53.1 \\
\hline $5-10$ years & 11 & 34.3 \\
\hline $11-15$ years & 2 & 6.3 \\
\hline More than 15 years & 2 & 6.3 \\
\hline
\end{tabular}




\subsection{Descriptive Statistics}

Table 2 revealed that the respondents have rather high inclinations towards all variables of interest with all of them were above their respective midpoints (Sekaran \& Bougie, 2010). It is worth noting that loyalty dimension of LMX scored the lowest mean score of 3.52. Cross reference to the demographic profiles clearly shown that the majority of the respondents $(53.1 \%)$ has worked with the current supervisor for a period of less than 5 years where the feature of loyalty has yet to be established. In terms of the main variable under study, OCB garnered the highest mean score of 3.94. Again cross referencing to the demographic profile revealed that the majority of the respondents $(78.1 \%)$ have spent their working life in the same organization where the majority of them have worked for a period exceeding 10 years. Thus, some elements of OCB have been embedded among the respondents themselves throughout the years they work together in the same organization.

Table 2. Descriptive statistics

\begin{tabular}{lll}
\hline Construct $(\mathrm{N}=32)$ & Mean & Standard Deviation \\
\hline Organizational Citizenship Behavior & 3.94 & 0.49 \\
Leader-Member Exchange & 3.91 & 0.58 \\
Affect & 4.11 & 0.67 \\
Loyalty & 3.52 & 0.84 \\
Contribution & 3.78 & 0.76 \\
Professional Respect & 4.24 & 0.66 \\
Organizational Communication & 3.80 & 0.56 \\
Interpersonal & 3.78 & 0.67 \\
Group & 3.75 & 0.56 \\
Organizational & 3.84 & 0.63 \\
Job Satisfaction & 3.90 & 0.62 \\
\hline
\end{tabular}

\subsection{Reliability Test}

The most popular test of inter-item consistency reliability is Cronbach's alpha coefficient where it indicates the extent to which an instrument is error free, consistent and stable across time and also across the various items in the scale (Sekaran \& Bougie, 2010). Hence, the Cronbach alpha coefficient test was employed to measure the internal consistency of the instruments used and the coefficient alpha of these variables were reported in Table 3.

Table 3. Cronbach's coefficient alpha of the variables

\begin{tabular}{llll}
\hline Construct & Dimension & No. of Items & Cronbach's Alpha \\
\hline Organizational Citizenship Behavior & Latent & 22 & 0.888 \\
Leader-Member Exchange (LMX) & Affect & 3 & 0.775 \\
& Loyalty & 3 & 0.682 \\
& Contribution & 3 & 0.787 \\
Organizational Communication & Professional respect & 3 & 0.858 \\
& Interpersonal & 10 & 0.884 \\
Job satisfaction & Group & 10 & 0.812 \\
& Organizational & 13 & 0.903 \\
\hline
\end{tabular}

As shown in Table 3, the Cronbach alpha test showed values ranging from a low of 0.682 (loyalty dimension of LMX construct) to a high of 0.941 (job satisfaction construct). These findings were in line with the benchmark suggested by Hair, et al. (2010) where coefficient of 0.60 is regarded to have an average reliability while coefficient of 0.70 and above indicates that the instrument has a high reliability standard. Although most researchers generally considered an alpha value of 0.70 as the acceptable level of reliability coefficient, lower coefficient is also acceptable (Nunnally, 1978; Sekaran \& Bougie, 2010). Thus, it can be concluded that data collected from the pilot study were reliable and have obtained the acceptable level of internal consistency. Hence, items in the loyalty dimension of LMX construct were retained as the alpha value of 0.682 was not that much lower that would create a problem in the generalizability of the questionnaire. Therefore, all items were included in the survey instrument and shall be used in the coming full scale research. 


\subsection{Normality Test}

An inspection from the regression standardized residual histogram (Figure 1) revealed that the data is normally distributed. In addition, the regression standardized residual (Figure 2) was also found to be normally distributed whereby the observed and expected values were found along the line, without any significant departures from it. Another approach that can be used to test the normality distribution is by examining the skewness and kurtosis values. Skewness is used to measure the symmetry of a distribution while kurtosis is used to measure the peakness or flatness of a distribution (Tabachnick and Fidell, 2007). Based on the results, the values of skewness and kurtosis revealed that the data was normally distributed where the skewness values was in the range of -1.691 to 0.054 . The value for kurtosis, on the other hand, was in the range of -1.391 to 5.625 well below the threshold of $+/-10$.

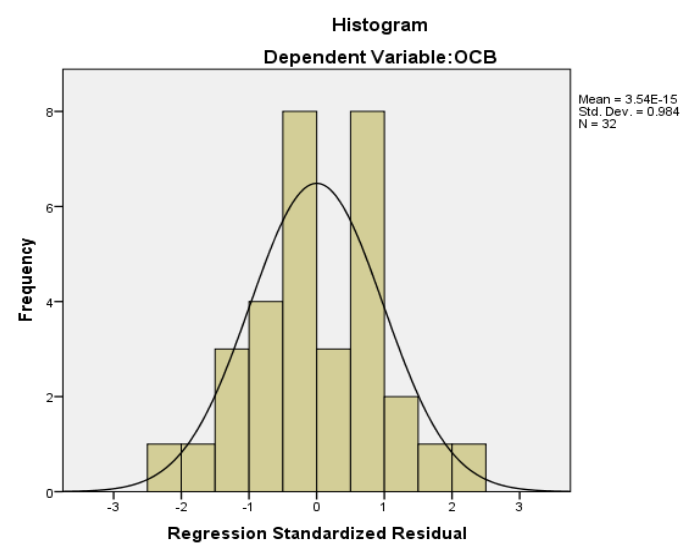

Figure 1. Regression standardized residual histogram

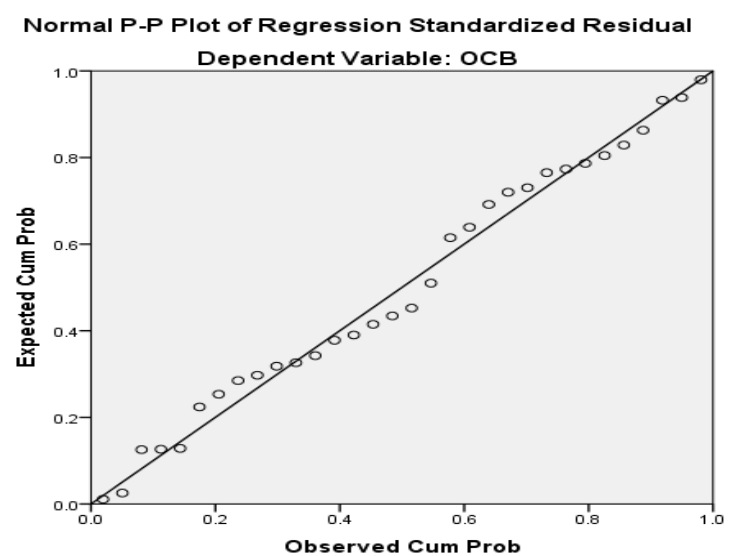

Figure 2. Normal P-P plot of regression standardized residual

\subsection{Linearity and Homocedasticity Tests}

As evidence from residual scatter plot (Figure 3) there is no clear relationship between the residuals and the predicted value of the dependent variable, indicating that linearity between them. Furthermore, the variance of residuals is considered to be equal or same for all predicted value of dependent variable which provided support of homocedasticity. Therefore, the assumptions of linearity and homocedasticity in the multivariate analyses have been fulfilled. 


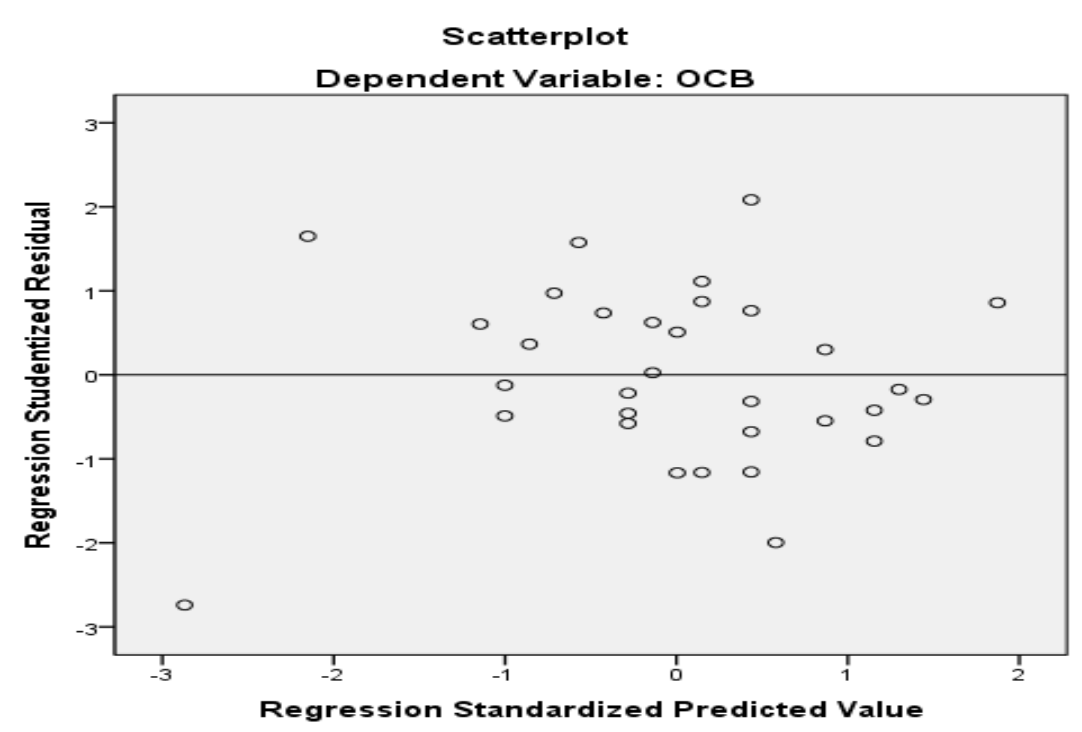

Figure 3. Scatter plot for linearity and homocedasticity

\section{Conclusion}

In conclusion, the survey instrument tested in this pilot study was reliable and valid based on a small sample size of 32 respondents. Analysis from the data revealed that Cronbach's alpha values indicated good measurement of reliability with all variables exceeded the 0.6 benchmark. Normality test using histogram and regression standardized residual (normal P-P plot) revealed that the data was normally distributed. Skewness and kurtosis analyses further indicated that the data was normal. Scatter plot provided evidence that assumptions of linearity and homocedasticity in multivariate analyses have been met. Demographic profile and descriptive statistics of the respondents were tabled out and analyzed.

The usefulness of this research tool in determining the effect of LMX, organizational communication and job satisfaction in promoting OCB among local governments' employees will be uncovered after the full scale study is carried out using a larger sample size covering local governments throughout Malaysia. More statistical analysis like t-test, analysis of variance, correlation analysis and regression analysis will be deployed to meet the objectives of this study.

\section{Acknowledgements}

The study is funded by Universiti Sultan Zainal Abidin under the university research grant and the authors would like to express their appreciations accordingly.

\section{References}

Alreck, P. L., \& Settle, R. B. (1995). The survey handbook (2nd ed.). Boston: Irwin.

Ansari, M. A., Kee, M. H., \& Aafaqi, R. (2007). Leader-member exchange and attitudinal outcomes: role of procedural justice climate. Leadership \& Organization Development Journal, 28(8), 690-709. http://dx.doi.org/10.1108/01437730710835443

Ayatse, F. A. (2005). Management Information System: A global perspective. Makurdi: Oracle.

Ayatse, F. A., \& Ikyanyon, D. N. (2012). Organizational communication, job stress and citizenship behavior of IT employees in Nigerian universities. Journal of Business Administration Research, 1(1), 99-105. http://dx.doi.org/10.5430/jbar.v1n1p99

Bateman, T. S., \& Organ, D. W. (1983). Job satisfaction and the good soldier: The relationship between affect and employee citizenship. Academy of Management Journal, 26, 587-595. http://dx.doi.org/10.2307/255908

Berger, B. K. (2008). Employee / Organizational communication. Institute of Public Relations, 15, 1-15.

Chahal, H., \& Mehta, S. (2011). Antecedents and consequences of Organizational Citizenship Behavior: A conceptual framework in reference to health care sector. Journal of Services Research, 10(2), 25-44.

Chughtai, A. A., \& Zafar, S. (2006). Antecedents and consequences of Organizational commitment among Pakistani university teachers. Applied HRM Research, 11(1), 39-64. 
Danilah, S., \& Siti Nabila, A. K. (2011). Accountability practice at local government of Malaysia. $2^{\text {nd }}$ International Conference on Business and Economics Research Proceeding.

Downs, C., \& Hazen, M. (1977). A factor-analytic study of communication satisfaction. Journal of Business Communication, 14(3), 63-74. http://dx.doi.org/10.1177/002194367701400306

Field, A. (2003). Discovering statistics using SPSS for windows (1st ed.). London: Sage Publication.

Foote, D. A., \& Tang, L. P. (2008). Job satisfaction and organizational citizenship behavior. Does team commitment make a difference in self-directed teams? Management Decisions, 46(6), 933-947. http://dx.doi.org/10.1108/00251740810882680

Gaye, L. R., Mills, G. E., \& Airasian, P. (2006). Educational research: Competencies for analysis and applications (8th ed.). Uppersaddle River, new Jersey: Pearson Educational International Inc.

Gray, J., \& Laidlaw, H. (2004). Improving the measurement of communication satisfaction. Management Communication Quarterly, 17(3), 425-448. http://dx.doi.org/10.1177/0893318903257980

Guffy, M. E., Rhoddes, K., \& Rogin, P. (2005). Business communications. Toronto: South-Western.

Hackett, R. D., Farh, J. L., Song, L. J., \& Lapierre, L. M. (2003). LMX and Organizational citizenship behavior: Examining the links within and across Western and Eastern samples. In Grean G. B. (Ed.), Dealing with diversity: The Series (pp. 219-264).

Hair, J. F., Black, W. C., Babin, B. J., \& Anderson, R. E. (2010). Multivariate data analysis: A global perspective. London: Pearson.

Hancer, M., \& George, T. R. (2003). Job satisfaction of restaurant employees: an empirical investigation using Minnesota Satisfaction Questionnaire. Journal of Hospitality \& Tourism Research, 27(1), 95-100. http://dx.doi.org/10.1177/1096348002238882

Harris, T. E., \& Nelson, M. D. (2008). Applied organizational communication: Theory and practice in global environment. New York: Lawrence Erlbaum.

Harrison, D. A., Newman, D. A., \& Roth, P. L. (2006). How important are job attitudes? Meta-analysis comparisons of integrative behavioral outcomes and time sequences. Academy of Management Journal, 49, 305-325. http://dx.doi.org/10.5465/AMJ.2006.20786077

Hazaman, S. A., \& Kalianan, M. (2008). From customer satisfaction to citizen satisfaction: Rethinking Local Government Service Delivery in Malaysia. Asian Social Science, 4(11), 87-92.

Hoffman, B. J., Blair, C. A., Meriac, J. P., \& Woehr, D. J. (2007). Expanding the Criterion Domain? A Quantitative Review of OCB Literature. Journal of Applied Psychology, 92(2), 555-556. http://dx.doi.org/10.1037/0021-9010.92.2.555

Hui, C., Law, K. S., \& Chen, Z. X. (1999). A structural equation model of the effects of negative affectivity, leader-member exchange and perceived job mobility on in-role and extra role performance: A Chinese case. Organizational Behavior and Human Decision Process, 77, 3-21. http://dx.doi.org/10.1006/obhd.1998.2812

Kandan, P., \& Ibrahim, A. (2010). A correlation study of leader-member exchange and organizational citizenship behavior in a public sector organization. Journal of Global Business and Economics, 1(1), 62-78.

Kandlousi, N. S., Ali, A. J., \& Abdollahi, A. (2010). Organizational Citizenship Behavior in concern of communication satisfaction: the role of formal and informal communication. International Journal of Business and Management, 5(10), 51-61.

Lapierre, L. M., \& Hackett, R. D. (2007). Trait conscientiousness, LMX, job satisfaction and organizational citizenship behavior: a test of an integrative model. Journal of Occupation and Organization Psychology, 80(3), 539-554. http://dx.doi.org/10.1348/096317906X154892

LePine, J. A., Erez, A., \& Johnson, D. E. (2002). The nature and dimensionality or organizational citizenship behavior: a critical review and meta-analysis. Journal of Applied Psychology, 87, 52-65. http://dx.doi.org/10.1037/0021-9010.87.1.52

Liden, R. C., \& Maslyn, J. M. (1998). Multidimensionality of leader-member exchange: An empiricial assessment through scale of development. Journal of Management, 24(1), 43-72. http://dx.doi.org/10.1177/014920639802400105

Liden, R. C., Wayne, S. J., \& Sparrowe, R. T. (1997). An examination of the mediating role of psychological 
empowerment on the relations between the job, interpersonal relationships and work outcomes. Journal of Applied Psychology, 85, 407-416. http://dx.doi.org/10.1037/0021-9010.85.3407

Malhotra, N. K. (2007). Marketing research. An applied orientation (4th ed.). New Jersey: Prentice Hall Upper Saddle River.

Manzoni, J., \& Barsoux, J. (2002). The set-up-to-fail syndrome. How good managers cause great people to fail. Boston: Harvard Business School Press.

Motowidlo, S. J. (2000). Some basics issues related to contextual performance and organizational citizenship behavior in human resource management. Human Resource Management Review, 10(1), 115. $\mathrm{http}: / / \mathrm{dx}$.doi.org/10.1037/0021-9010.71.4.618

Mueller, B. H., \& Lee, J. (2002). Leader-member exchange and organizational communication satisfaction in multiple contexts. The Journal of Business Communication, 39(2), 220-244. http://dx.doi.org/10.1177/002194360203900204

Murphy, G., Athanasou, J., \& King, N. (2002). Job satisfaction and organizational citizenship behavior: A study of Australian human-service professionals. Journal of Managerial Psychology, 17(4), 287-297. http://dx.doi.org/10.1108/02683940210428092

Normala, A. I., \& Syed, S. A. (2009). Leader member exchange and organizational citizenship behavior: The mediating impact of self-esteem. International Journal of Business and Management, 4(3), 52-61.

Nunnally, J. C. (1978). Psychometric Theory (2nd ed.). New York: McGraw Hill Book Company.

Organ, D. W. (1988). Organizational Citizenship behavior. The good soldier syndrome. Lexington, MA: Lexington Books.

Organ, D. W., \& Ryan, K. (1995). A meta-analytic review of attitudinal and dispositional predictors of organizational citizenship behavior. Personnel Psychology, 48, 775-802. http://dx.doi.org/10.1111/j.1744-6570.1995.tb01781.x

Podsakoff, N. P., Whiting, S. W., Podsakoff, P. M., \& Blume, B. D. (2009). Individual and organizational level consequences of organizational citizenship behaviors: A meta-analysis. Journal of Applied Psychology, 94(1), 122-141. http://dx.doi.org/10.1037/a0013079

Podsakoff, P. M., Mackenzie, S. B., Moorman, R. H., \& Fetter, R. (1990). Transformational leaders' behaviours and their effects on followers' trust in leader, satisfaction and organizational citizenship behaviour. Leadership Quarterly, 1(2), 107-142. http://dx.doi.org/10.1016/1048-9843(90)900009-7

Public Complaints Bureau, Annual Reports 2007 - 2011. Retrieved from http://www.pccb.gov.my/bpaweb.php?lang=E

Sekaran, U., \& Bougie, R. (2010). Research methods for business: A skill building approach (5th ed.). Chichester: John Wiley \& Sons Ltd.

Sidek, M. N. (2000). Reka bentuk penyelidikan: Falsafah, teori dan praktis. Universiti Putra Malaysia, Selangor.

Simon, T., \& Peterson, R. (2000). Task conflict and relationship conflict in top management teams: The pivotal role of intergroup trust. Journal of Applied Psychology, 85, 102-111. http://dx.doi.org/10.1037/0021-9010.85.1.102

Tabachnick, B. G., \& Fidell, L. S. (2007). Uisng multivariate statistics (5th ed.). Boston: Pearson Education Inc.

Vigoda, E., \& Golembiewski, R. T. (2001). Citizenship behavior and the spirit of new managerialism: A theoretical framework and challenges for governance. The American Review of Public Administration, 31(3), 273-295. http://dx.doi.org/10.1177/02750740122064956

Wang, H., Law, K. S., Hackett, R. D., Wang, D., \& Chen, Z. X. (2005). Leader-member exchange as a mediator of the relationship between transformational leadership and follwers' performance and organizational citizenship behavior. Academy of Management Journal, 48, 420-432. http://dx.doi.org/10.5465/AMJ.2005.17407908

Weiss, D. J., Dawis, R. V., England, G. W., \& Lofquist, L. H. (1967). Manual for the Minnesota Satisfaction Questionnaires. Minneapolis: University of Minnesota.

Yulk, G. A. (2006). Leadership in organizations (6th ed.). Upper Saddle River, NJ: Prentice Hall.

Zaherawati, Z., Zuriawati, Z., \& Mohd, Z. H. (2010). Environmental functions provided by Malaysian local 
government: User's perception. Journal of Social Sciences, 6(2), $296-302$. http://dx.doi.org/10.3844/jssp.2010.296.302

Zellars, K. L., Tepper, B. J., \& Duffy, M. K. (2002). Abusive supervision and subordinates' organizational citizenship behavior. Journal of Applied Psychology, 87(6), 1068-1076. http://dx.doi.org/10.1037/0021-9010.87.6.1068 